\title{
Pemanfaatan Media Big Book untuk Meningkatkan Kemampuan Membaca Permulaan pada Siswa Kelas II SD Negeri Gunung Sari II Makassar
}

\author{
Syamsiah Djaga ${ }^{1}$, Andi Dewi Riangtati ${ }^{2}$, Hikmawati Usman ${ }^{3}$ \\ ${ }_{1,2,3}$ PGSD, Fakultas Ilmu Pendidikan, Universitas Negeri Makassar \\ 1 syamsiahdjaga@gmail.com \\ andi.dewi.riang@unm.ac.id \\ 3hikmawati@unm.ac.id
}

\begin{abstract}
ABSTRAK
Tujuan penelitian adalah untuk mendeskripsikan pemanfaatan media big book dalam meningkatkan kemampuan membaca permulaan. Penelitian ini merupakan penelitian tindakan kelas yang dilakukan dalam 2 siklus. Subjek penelitian adalah guru dan siswa kelas II SD. Pengumpulan data menggunakan observasi, tes kemampuan membaca, dan dokumentasi. Analisis data yang digunakan adalah deskriptif kualitatif. Hasil analisis dapat dilihat dari siklus I aktivitas mengajar guru dan aktivitas belajar siswa berada pada kategori cukup, dan siklus II aktivitas mengajar guru dan aktivitas belajar siswa berada pada kategori baik. Hasil belajar pada siklus I belum mencapai ketuntasan secara klasikal dan siklus II sudah tercapai ketuntasan secara klasikal. Kesimpulan dalam penelitian ini adalah dengan pemanfaatan media big book dapat meningkatkan kemampuan membaca permulaan pada siswa kelas II SDN Gunung Sari II Makassar.
\end{abstract}

Kata kunci: Media Big Book, kemampuan membaca

\begin{abstract}
The purpose of this research is to describe the use of big book media in improving the beginning reading skills. This research is a classroom action research conducted in 2 cycles. The research subjects were teachers and grade II elementary school students. Data collection uses observation, reading ability tests, and documentation. Analysis of the data used is descriptive qualitative. The results of the analysis can be seen from the first cycle of teacher teaching activities and student learning activities are in the sufficient category, and the second cycle of teacher teaching activities and student learning activities are in both categories. Learning outcomes in the first cycle have not yet reached classical completeness and the second cycle has reached classical completeness. The conclusion in this study is the use of big book media can improve the ability to read the beginning of class II students at SDN Gunung Sari II Makassar.
\end{abstract}

Keywords: Big Book Media, Reading Ability

\section{PENDAHULUAN}

Membaca pada siswa Sekolah Dasar (SD) berperan penting dalam kesuksesan belajar. Membaca perlu diajarkan dengan matang karena terkait pada tahapan yang lebih kompleks. "Tujuan yang dapat dicapai melalui pengajaran membaca yaitu mengembangkan nilai-nilai moral, kemampuan bernalar, serta kreativitas" (Akhadiah dan Zuhdi, 1992/1993:29)

Pembelajaran Bahasa Indonesia di Sekolah Dasar (SD) berdasarkan Kurikulum Tingkat Satuan Pendidikan (KTSP) lebih menekankan keterlibatan anak dalam belajar, hal ini terlihat pada standar kompentensi dalam Badan Standar Nasional Pendidikan (BNSP,
2006) yang harus dikuasai oleh siswa yaitu kompentensi mendengarkan, berbicara, membaca, dan menulis

Pentingnya pembelajaran membaca juga terdapat dalam Undang-Undang Sistem Pendidikan Nasional tahun 2003 pada Bab III pasal 4 ayat 4 tentang Prinsip-prinsip Penyelenggaraan Pendidikan disebutkan bahwa pendidikan diselenggarakan dengan mengembangkan budaya membaca, menulis dan berhitung bagi segenap warga masyarakat. Secara garis besar ayat tersebut menjelaskan bahwa membaca bagi warga masyarakat sangat penting. Untuk itu pembelajaran membaca juga harus 
dilaksanakan sesuai dengan prinsip penyelenggaraan pendidikan.

Kegiatan membaca menjadi kegiatan yang sangat diperlukan oleh siapa saja yang ingin maju dan meningkatkan diri. Oleh karena itu, pembelajaran membaca di sekolah dasar mempunyai peranan yang sangat penting. Dalam pembelajaran membaca guru dapat memilih wacana-wacana yang berkaitan dengan tokoh nasional, kepahlawanan, kenusantaraan, dan kepariwisataan. Selain itu melalui contoh pembelajaran membaca, guru dapat mengembangkan nilai-nilai moral, kemampuan bernalar dan kreativitas siswanya.

Membaca permulaan sebagai kemampuan dasar membaca merupakan alat bagi siswa untuk mengetahui makna dari isi mata pelajaran yang dipelajari di sekolah. Makin cepat siswa dapat membaca makin besar peluang untuk memahami makna isi pelajaran di sekolah. Dalam pembelajaran membaca seorang guru harus mampu memilih bahan pembelajaran yang tepat bagi siswanya. "Pemilihan bahan pengajaran harus memperhatikan beberapa prinsip diantaranya: (1) bahan bacaan harus disesuaikan dengan kesiapan siswa; (2) tujuan pengajaran membaca ialah mengembangkan berbagai aspek kemampuan siswa; (3) kondisi di sekolah dan lingkungan masyarakat perlu diperhatikan" ( Akhadiah, 1992/ 1993:14-15).

Kemampuan membaca selalu ada dalam setiap tema pembelajaran. Hal tersebut menunjukkan pentingnya penguasaan kemampuan membaca, karena kemampuan membaca merupakan salah satu standar kemampuan bahasa dan sastra Indonesia yang harus dicapai dalam setiap jenjang pendidikan, termasuk di jenjang sekolah dasar. Kemampuan membaca menjadi dasar yang utama bagi pengajaran bahasa serta pengajaran mata pelajaran yang lain. Dalam hal ini, membaca merupakan salah satu aspek kemampuan berbahasa yang harus dikuasai oleh siswa sekolah dasar terutama pada kelas awal. Melalui kegiatan ini, siswa dapat memperoleh berbagai informasi (Hastuti, 2012:1).

Kenyataan yang terjadi di lapangan saat ini sangat jauh dari tujuan pembelajaran membaca siswa di Indonesia masih mempunyai rata-rata kemampuan membaca yang rendah dibandingkan negara lainnya. Penelitian tersebut dilakukan oleh The International Association for The Evaluation of Educational Achievement tahun
2006 yang menyatakan bahwa dari 45 negara di dunia, Indonesia berada pada peringkat 41 atau nomor empat dari bawah (Litbang. Kemdikbud.go.id).

Hal tersebut diperkuat dari data hasil observasi dan wawancara pada guru dan siswa yang dilakukan oleh peneliti pada bulan April 2015 terungkap bahwa hasil pembelajaran membaca permulaan kompetensi dasar (KD): menyimpulkan isi teks pendek (10-15 kalimat) yang dibaca dengan membaca lancar pada kelas II SD Negeri Gunung Sari II Kecamatan Rappocini Kota Makassar nilai ketuntasan formatif hanya mencapai $42 \%$. Kemampuan membaca permulaan di kelas II yang berjumlah 21 siswa. Terdapat 6 siswa $(28.57 \%)$ yang belum dapat membaca atau masih mengeja dan 9 siswa $(42.85 \%)$ yang kurang lancar dalam membaca, dan 6 siswa (28.57\% ) yang sudah bisa membaca secara lancar. Sedangkan kriteria ketuntasan minimal (KKM) yang ditetapkan adalah 70. Oleh karena itu, dapat dikatakan bahwa pembelajaran membaca permulaan di kelas II mengalami permasalahan yaitu masih banyaknya siswa yang belum mampu membaca secara lancar dan tepat, serta kurang memperhatikan lafal, intonasi dan tanda baca.

Setelah diidentifikasi ternyata ada beberapa masalah yang terjadi dalam pembelajaran membaca, yaitu: proses pembelajaran yang kurang menarik dan menyenangkan sehingga tidak menumbuhkan motivasi belajar membaca pada diri siswa, serta penggunaan peralatan/media dalam pembelajaran yang kurang memadai hanya mengandalkan buku ajar.

Menurut Sadiman, dkk (2009:7) Media pembelajaran adalah " Segala sesuatu yang dapat digunakan untuk menyalurkan pesan dari pengirim ke penerima sehingga dapat merangsang pikiran, perasaan, perhatian, dan minat serta perhatian siswa sedemikian rupa sehingga proses belajar terjadi”.

Selanjutnya Kasihani K.E Suyanto (2007:26) menjelaskan bahwa, ada beberapa hal yang dapat membantu dalam pembelajaran membaca, yaitu: (1) menggunakan gambar sebagai alat bantu; (2) memberikan pertanyaan-pertanyaan; (3) menunjukkan judul dan meminta siswa untuk menebaknya; dan (4) kalimat bacaan tidak terlalu panjang agar tidak membingungkan siswa.

Dari paparan kedua pendapat di atas diperoleh makna bahwa dalam pembelajaran 
membaca harus menggunakan media yang dapat membuat siswa tertarik untuk belajar. Media untuk membaca perlu disertai gambar atau ilustrasi yang jelas supaya siswa mengetahui alur cerita yang di baca.

Media yang dipilih harus disesuaikan dengan isi bacaan. Saat ini sudah banyak media yang diguna-kan untuk mengajarkan membaca permulaan pada siswa seperti kartu kata, gambar seri, dan buku cerita bergambar. Selain media tersebut di dalam penelitian ini akan menggunakan media Big Book dalam membaca permulaan dan guru akan membuatnya sendiri.

Big Book merupakan salah satu media literasi di kelas awal. Literasi adalah "kemampuan berbahasa seseorang (menyimak, berbicara, membaca, dan menulis) untuk berkomunikasi dengan cara yang berbeda sesuai dengan tujuannya". Usaid (2014:2).

Big Book adalah "buku bacaan yang memiliki ukuran, tulisan, dan gambar yang besar." Usaid (2014:42). Sedangkan Aisyah dan Arismanti (2000) menyatakan bahwa Big Book merupakan buku cerita yang berkarakteristik khusus yang dibesarkan, baik teks maupun gambarnya, untuk memungkinkan terjadinya kegiatan membaca bersama antara guru dan murid. Berdasarkan kedua pendapat tersebut, dapat disimpulkan bahwa Big Book merupakan buku bacaan yang mempunyai karakteristik ukuran, tulisan serta gambar yang besar yang dapat dijadikan sebagai salah satu media literasi. Maka, Media Big Book adalah suatu bentuk perantara yang memuat materi pembelajaran serta memiliki karakteristik dengan ukuran tulisan, serta gambar yang besar yang dapat dijadikan sebagai salah satu media literasi.

Kasihani K.E. Suyanto (2010: 104) menjelaskan bahwa Big Books merupakan salah satu media yang disenangi anak-anak dan dapat dibuat sendiri oleh guru. Buku berukuran besar ini biasanya digunakan untuk anak kelas rendah. Di dalamnya berisi cerita singkat dengan tulisan besar diberi gambar yang warna warni. Anak bisa membaca sendiri atau mendengarkan ceritanya dari guru. Lynch (Ika dan Bambang, 2012: 9) mengatakan bahwa Big Books dapat menjadi motivasi yang kuat untuk belajar tentang pengucapan kata, bentuk dan jenis kata seperti kata majemuk, kata kerja, singkatan, maupun sajak. Kebiasaan dalam mendengarkan atau membaca cerita akan menambah kosa kata.

Dari dua pendapat di atas, dapat disimpulkan bahwa Big Books merupakan media untuk belajar pengucapan kata, bentuk maupun jenis kata yang digemari oleh anakanak. Big Books digunakan di kelas rendah yang berisi cerita singkat disertai gambar.

Karges-Bone (Usaid, 2014:43) menyatakan agar pembelajaran bahasa dapat lebih efektif dan berhasil, sebuah Big Book sebaiknya memiliki ciri-ciri antara lain: "1) Cerita singkat (10-15 halaman); 2) Pola Kalimat jelas; 3) Gambar memiliki makna; 4) Jenis dan ukuran huruf jelas terbaca; serta 5) Jalan cerita mudah dipahami".

Berdasarkan ciri-ciri tersebut, maka dapat disimpulkan bahwa Big Book memiliki ciri-ciri yakni: 1) Cerita singkat dengan pola kalimat yang jelas disertai dengan tanda baca; 2) Gambar yang sesuai dengan isi cerita sehingga memudahkan pemahaman siswa dalam membaca; 3) Jenis dan ukuran huruf yang jelas dan dapat dijadikan contoh oleh siswa dalam menulis.

Media Big Book merupakan media yang dapat digunakan dalam proses pembelajaran, dimana media Big Book berarti buku besar, baik tulisan ataupun gambarnya, yang merupakan cerita singkat yang setiap gambarnya memiliki keterkaitan antara satu dengan gambar yang lainnya.

Langkah-langkah penggunaan media Big Book dalam pembelajaran di sekolah khususnya di kelas awal, dikemukakan oleh Usaid (2014:88), yakni:

1. Siapkan alat/bahan yang dibutuhkan, yaitu Big Book/teks cerita sederhana sesuai dengan tema di kelas awal;

2. Sebelum menggunakan Big Book dalam pemodelan, bacalah terlebih dahulu Big Book sampai benarbenar memahami isinya;

3. Pilihlah strategi pemodelan sesuai dengan kondisi kelas. Misalnya jika kelas terlalu padat, maka aturlah kelas dengan cara menarik kursi dan membuatnya berjajar di depan kelas untuk duduk lesehan. Jika memungkinkan, kegiatan pemodelan membaca dapat dilakukan di luar kelas. Misalnya di bawah pohon rindang, di taman sekolah, atau di teras. Pilihlah tempat yang kondusif;

4. Lakukan pemodelan dengan cara membaca kata demi kata sambil menunjuk setiap kata yang dilafalkan; 
5. Mintalah setiap siswa untuk mengucap ulang kata yang dibacakan guru;

6. Saat membacakan cerita, perhatikan intonasi bertanya. Hal itu menjadi salah satu cara implisit untuk memperkenalkan tanda baca;

7. Ulangi kembali membaca kata jika diperlukan;

8. Ketika membaca Big Book, ajukan pertanyaan- pertanyaan pancingan untuk membantu pemahaman siswa. Misal-nya, apakah warna baju yang dipakai tokoh? Pertanyaan itu dilanjutkan dengan pertanyaan: apa warna kesukaan kalian?;

9. Setelah selesai membaca, mintalah beberapa orang secara bergantian untuk menceritakan kembali isi cerita tersebut.

Langkah-langkah Big Book di atas dapat disimpulkan sebagai berikut: 1) Memilih strategi pemodelan yang sesuai dengan jumlah siswa sehingga memungkinkan setiap siswa dapat membaca Big Book secara bersamasama; 2) Melakukan pemodelan dengan cara membaca kata demi kata sambil menunjuk kata yang dilafalkan serta memperhatikan intonasi saat membaca; 3) Meminta siswa untuk mengucap ulang kata yang dibacakan guru; 4) Jika ada siswa yang lambat dalam membaca, kegiatan membaca dapat diulangi sesuai dengan kondisi; 4) Saat membaca, guru dapat mengajukan pertanyaan-pertanyaan pancingan untuk membantu pemaha-man siswa; 5) Setelah selesai membaca, guru meminta beberapa orang siswa untuk menceritakan kembali isi cerita tersebut.

Perbedaan gaya belajar, minat, intelegensi, serta keterbatasan daya indera dapat diatasi dengan pemanfaatan media pembelajaran. Berbagai cara yang dapat digunakan guru dalam mengatasi kesulitan belajar membaca permulaan yaitu menggunakan media Big Book berdasarkan pandangan para ahli literasi di negara maju yang dapat kita lihat di kelas-kelas rendah dan pendidikan pra-sekolah seperti di Eropa, Amerika, dan Australia. Salah satu kegiatan tersebut adalah dengan membacakan cerita kepada anak.

Kegiatan membaca cerita diasumsikan dapat mengembangkan kemampuan berbahasa, dan mengajarkan baca-tulis. Hal ini, dapat dilakukan dengan menggunakan sebuah Big Book (buku besar). Big Book dapat digunakan di kelas awal karena memiliki karakteristik yang sesuai dengan kebutuhan siswa dengan isi dan topiknya dapat di tentukan sendiri oleh guru sesuai dengan minat siswa ataupun tema pelajaran.

Penelitian yang relevan dengan judul penelitian ini, telah dilakukan oleh peneliti terdahulu yaitu Aisyah dan Arismanti (2000) dengan judul Penggunaan Buku Besar (Big Book) dalam Mengembangkan Kemampuan Berbahasa Anak (Dengar, Cakap, Baca, Tulis) di Taman Kanak-kanak dengan kemampuan awal sebelum penelitian dilakukan menunjukkan bahwa siswa yang sudah mengenal huruf sebanyak 13 siswa $(46,43 \%)$. Sisanya sebanyak 15 siswa $(53,57 \%)$ belum dapat mengenal huruf sama sekali.

Setelah penerapan Big Book pada penelitian tersebut menunjukkan bahwa terdapat 4 siswa dari 28 siswa $(14,29 \%)$ yang belum dapat membaca dan menulis, sementara siswa lainnya yakni sekitar $(85,71 \%)$ sudah dapat membaca dan menulis mulai dari per kata sampai yang sudah dapat membaca dan menulis serta memaknai suatu buku cerita.

Berdasarkan uraian latar belakang yang telah dipaparkan, maka peneliti bersama guru bermaksud mengadakan Penelitian Tindakan Kelas (PTK) yang diasumsikan berguna untuk memberikan solusi yang terbaik untuk mengatasi kesulitan membaca permulaan siswa pada mata pelajaran bahasa Indonesia dengan judul Pemanfaatan Media Big Book untuk Meningkatkan Kemampuan Membaca Permulaan Siswa Kelas II SD Negeri Gunung Sari II Kecamatan Rappocini Kota Makassar.

Masalah penelitian ini bagaimana pemanfaatan media Big Book dalam pembelajaran membaca permulaan siswa kelas II SD Negeri Gunung Sari II Kecamatan Rappocini Kota Makassar?. Penelitian ini diharapkan siswa memiliki kemampuan membaca yang baik dari segi pelafalan, intonasi, dan kelancaran. Hal inilah sangat perlu dicermati dalam proses pembelajaran sehingga pembelajaran membaca dapat berhasil dengan baik.

\section{METODE PENELITIAN}

Metode yang digunakan dalam penelitian ini adalah metode kualitatif dengan bentuk penelitian Tindakan Kelas (PTK). Rancangan penelitian disusun dalam bentuk siklus berdaur ulang meliputi perencanaan, pelaksanaan, observasi, dan refleksi, Arikunto (2012:16).

Fokus penelitian ini mengkaji pemanfaatan media Big Book dan kemampuan 
membaca permulaan. Subjek penelitian tindakan kelas ini adalah guru wali kelas dan siswa kelas II SD Negeri Gunung Sari II Kecamatan Rappocini Kota Makassar yang aktif terdaftar pada semester ganjil tahun pelajaran 2015/2016 dengan jumlah siswa 21 orang yang terdiri dari 16 orang laki-laki dan 5 orang perempuan. Sedangkan peneliti sendiri bertindak sebagai observer.

Penelitian tindakan kelas ini, dilaksanakan dua siklus dimana setiap siklus dilaksanakan tiga kali pertemuan dan setiap pertemuan menggunakan alokasi waktu 3 x 35 menit. Pada setiap siklus dilaksanakan penyusunan rancangan pelaksanaan pembelajaran (RPP), mengobservasi guru mengajar dan siswa belajar. Menilai siswa pada saat membaca dengan menggunakan media Big Book. Pada saat membaca dinilai kemampuan membacanya dari segi pelafalan, intonasi, dan kelancaran. Hasil penilaian pada setiap siklus menentukan apakah guru dan siswa berhasil dalam proses mengajar dan belajar serta menentukan aktivitas pada siklus berikutnya.

Teknik analisis data dilakukan adalah teknik analisis data kualitatif deskriptif. menurut Miles dan Huberman (Sugiyono, 2011:337) "analisis data kualitatif deskriptif dilakukan dengan tiga tahap yaitu a) reduksi data, b) penyajian data c) Menarik Kesimpulan dan Verifikasi Data. Kegiatan ini mencakup pencarian makna data serta memberikan penjelasan. Selanjutnya dilakukan kegiatan verifikasi yaitu menguji kebenaran dan kecocokan makna-makna yang muncul dari data diperoleh dari lapangan.

Indikator keberhasilan dalam penelitian ini terdiri dari indikator proses dan indikator hasil. Indikator proses dalam penelitian ini yakni apabila terjadi perbaikan aktivitas belajar dan keaktifan siswa melalui pemanfaatan media Big Book. Indikator keberhasilan proses ditetapkan dengan standar, yakni dikategorikan berhasil jika pelaksanaan skenario pembelajaran $\geq 80 \%$. Adapun dari segi hasil adalah penelitian dikatakan berhasil apabila $75 \%$ dari jumlah siswa mendapatkan nilai $\geq 70$

\section{HASIL \& PEMBAHASAN}

Hasil penelitian berupa (1) data observasi terhadap aktivitas mengajar guru, (2) aktivitas belajar siswa yang menggunakan lembar observasi, dan (3) data kemampuan membaca siswa yang diperoleh melalui tes kemampuan membaca dengan menggunakan media Big Book disetiap pertemuan baik siklus I maupun pada siklus II serta data yang diperoleh dihitung frekuensi dan persentasenya sebagai acuan untuk penafsiran analisis deskriptif. Pelaksanaan tindakan tiap siklus terdiri dari tiga kali pertemuan untuk proses pembelajaran dan diakhir pembelajaran dilaksanakan tes kemampuan membaca.

\section{Hasil Aktivitas Mengajar Guru dengan Memanfaatkan Media Big Book dalam Pembelajaran.}

Aspek-aspek yang dinilai dari aktivitas mengajar guru dengan memanfaatkan media Big Book adalah sebagai berikut. 1) memilih strategi pemodelan sesuai dengan kondisi kelas, 2) melakukan pemodelan dengan cara membaca kata demi kata sambil menunjuk setiap kata yang dilafalkan, 3) meminta siswa untuk mengucap ulang kata yang dibacakan, 4) memperhatikan intonasi untuk memperkenalkan tanda baca sederhana, 5) Guru mengulangi kembali membaca kalimat tertentu, 6) Guru memberi pertanyaanpertanyaan pancingan untuk membantu pemahaman siswa, 7) Guru meminta beberapa orang siswa untuk menceritakan kembali isi cerita.

Berdasarkan data dan hasil observasi mengajar guru dengan memanfaatkan media Big Book pada siklus I pertemuan I berada pada kategori cukup begitu pula pada pertemuan kedua dan ketiga masih berada pada kategori cukup. Sedangkan pada siklus ke II dapat disimpulkan bahwa hasil aktivitas mengajar guru pada siklus ke dua secara umum mengalami perbaikan. Hal itu dapat dilihat dari hasil observasi mengajar guru pada pertemuan pertama dengan kategori baik, pertemuan kedua dan ketiga berada pada kategori baik. Sehingga dapat disimpulkan bahwa aktivitas mengajar guru pada siklus ke dua sudah mengalami perbaikan sudah berada pada ratarata kategori baik, walaupun masih ada bagian-bagian yang masih perlu diperbaiki seperti memperhatikan siswa yang masih kurang dalam membacanya. 


\section{Hasil Observasi Aktivitas Belajar Siswa dalam Proses Pembelajaran dengan Memanfaatkan Media Big Book pada Siklus I Dan Siklus II}

Aspek yang dinilai pada observasi aktivitas belajar siswa dalam proses pembelajaran dengan menggunakan media Big Book pada siklus I dan Siklus II adalah sebagai berikut: 1) Siswa mengikuti strategi pemodelan yang diinstruksikan guru, 2) Siswa membaca kata demi kata yang ditunjuk guru, 3) Siswa mengucap ulang kata yang dibacakan guru, 4) Siswa mengikuti intonasi guru saat membaca, 5) Siswa mengulangi kembali membaca kalimat yang tertentu yang dibacakan guru, 6) Siswa menjawab pertanyaan-pertanyaan pancingan yang diajukan guru, 7) Beberapa siswa menceritakan kembali isi cerita.

Berdasarkan data dari hasil observasi pada siklus I aktivitas belajar siswa menunjukkan bahwa aktivitas belajar membaca siswa dengan memanfaatkan media Big Book secara umum mengalami perbaikan. Hal itu dapat dilihat dari persentase aktivitas belajar siswa pada pertemuan pertama dengan kategori kurang, pertemuan pada aktivitas belajar siswa berada pada kategori cukup dan pertemuan ketiga masuk kategori baik. Sedangkan hasil observasi aktivitas belajar siswa pada siklus ke II pada pertemuan pertama dan masuk pada kategori cukup dan pada pertemuan kedua dan ke tiga terjadi perbaikan masuk kategori baik. Uraian tersebut di atas dapat ditarik kesimpulan bahwa pada siklus II aktivitas belajar siswa menunjukkan bahwa pada siklus II aktivitas belajar dengan memanfaatkan media Big Book secara umum mengalami perbaikan dan masuk kategori baik.

\section{Hasil Tes Kemampuan Membaca Permulaan dengan Pemanfaatan Media Big Book pada Siklus I dan Siklus II.}

Aspek yang akan dinilai dalam kemampuan membaca permulaan adalah 1) aspek pelafalan, 2) aspek intonasi, dan 3) aspek kelancaran.

Hasil kemampuan siswa dalam membaca permulaan dengan pemanfaatan media Big Book pada siklus I, frekuensi ketuntasan yang dicapai siswa yang berada pada kategori tidak tuntas pada aspek pelafalan sebanyak 12 siswa dengan persentase $42.85 \%$ sedangkan pada kategori tuntas terdapat 9 siswa dengan persentase $61,90 \%$. Pada aspek intonasi sebanyak 12 siswa atau $42.85 \%$ dan pada kategori tuntas terdapat 9 siswa atau $61.90 \%$. sedangkan pada kategori tidak tuntas pada aspek kelancaran terdapat 8 siswa atau $38.09 \%$ dan masuk kategori tuntas 13 siswa atau $61.90 \%$. Berdasarkan persentase ketuntasan hasil belajar pada kemampuan membaca permulaan siswa pada siklus I belum mencapai indikator ketuntasan secara klasikal 49.2\% kurang dari $75 \%$ siswa memperoleh nilai sesuai dengan standar Kriteria Ketuntasan Minimal yakni 70 .

Sedangkan pada siklus ke II hasil kemampuan siswa dalam membaca permulaan dengan pemanfaatan media Big Book, frekuensi ketuntasan yang dicapai siswa pada aspek pelafalan yang berada pada kategori tidak tuntas sebanyak 6 siswa dengan persentase $28.57 \%$ sedangkan pada kategori tuntas terdapat 15 siswa dengan persentase $71.42 \%$. Pada aspek intonasi berada pada kategori tidak tuntas 8 siswa atau $38.09 \%$, sedangkan pada kategori tuntas sebanyak 13 siswa atau $61.90 \%$. Pada aspek kelancaran 5 siswa berada pada kategori tidak tuntas atau $23.80 \%$ dan 16 siswa yang berada pada kategori tuntas atau $76.19 \%$. Berdasarkan persentase ketuntasan hasil belajar pada kemampuan membaca siswa pada siklus II tiap aspeknya mengalami peningkatan dan sudah mencapai indikator ketuntasan secara klasikal karena lebih dari $75 \%$ siswa memperoleh nilai sesuai dengan standar Kriteria Ketuntasan Minimal yakni 70 .

\section{Pembahasan}

Hal yang akan dibahas pada bagian ini adalah pemanfaatan media Big Book untuk meningkatkan kemampuan membaca permulaan siswa pada mata pelajaran bahasa Indonesia di kelas II SD Negeri Gunung Sari II Kecamatan Rappocini Kota Makassar. Berdasarkan hasil pelaksanaan siklus I, dapat diketahui bahwa pemanfaatan media Big Book belum terlaksana secara maksimal. Pada pertemuan I aktivitas guru berada pada kategori baik, serta aktivitas siswa berada pada kategori cukup.

Adapun pertemuan I, aktivitas guru berada pada kategori cukup atau $66.66 \%$ dan aktivitas belajar siswa berada pada kategori kurang atau $47.61 \%$. Pada pertemuan II mengalami perbaikan dari pertemuan sebelumnya yakni aktivitas guru berada pada kategori cukup (76.19\%) dan aktivitas siswa berada kategori cukup (76.19). Untuk pertemuan III, aktivitas guru masuk pada kategori baik $(85.71 \%)$ dan aktivitas belajar 
siswa mengalami perbaikan berada pada kategori baik (85.71). Meskipun demikian, untuk hasil kemampuan membaca siswa belum mencapai indikator yang telah ditetapkan. Berdasarkan data yang diperoleh, dari 21 siswa kelas II masih ada 8 siswa yang belum memenuhi Kriteria Ketuntasan Minimal (KKM) yaitu 70 sehingga ketuntasan klasikal yang dicapai pada siklus I, hanya $60.31 \%$

Berdasarkan hasil pelaksanaan siklus II, diketahui adanya peningkatan kualitas pembelajaran, baik dari indikator keberhasilan proses dan indikator keberhasilan hasil. Ditinjau dari indikator keberhasilan proses telah dianggap mencapai target. Pada pertemuan I, diketahui aktivitas guru berada pada persentase $80,95 \%$ dengan kategori baik, sedangkan aktivitas siswa juga berada pada persentase $66,67 \%$ dengan kategori cukup. Pada pertemuan II, aktivitas guru tidak mengalami peningkatan kualitas pembelajaran jika dilihat dari persentase pencapaian, yakni aktivitas guru berada pada persentase $90.47 \%$ dengan kategori baik, namun pada aktivitas siswa menunjukkan peningkatan yang dapat dilihat dari persentase pencapaian yakni $76,19 \%$ dengan kategori cukup. Pada pertemuan III, aktivitas mengajar guru berada pada persentase $95.23 \%$ dengan kategori baik dan aktivitas belajar siswa berada pada kategori baik dengan presentasi $85.71 \%$. Ditinjau dari indikator keberhasilan hasil kemampuan membaca siswa diketahui bahwa hasil tes siklus II telah mencapai target. Dari 21 siswa, terdapat 4 siswa $(19.04 \%)$ yang memperoleh nilai kurang dari 70 .

Berdasarkan pembahasan di atas, dapat diketahui bahwa media Big Book dapat meningkatkan kemampuan membaca permulaan siswa dikarenakan media Big Book adalah buku bacaan yang memiliki ukuran, tulisan, dan gambar yang besar. Sehingga siswa memiliki ketertarikan terhadap apa yang dipelajarinya dengan menggunakan bantuan media Big Book, yang dapat membantu siswa dalam mengoptimal-kan kemampuan membaca dan menulisnya Usaid (2014). Sebagaimana hal tersebut dapat dilihat pada hasil kemampuan membaca permulaan siswa pada siklus II yang terbukti meningkat dari siklus I.

Berdasarkan hasil observasi aktivitas mengajar guru, hasil observasi aktivitas belajar siswa, serta peningkatan nilai rata-rata kemampuan membaca siswa dari siklus I ke siklus II, maka dapat disimpulkan bahwa pemanfaatan media Big Book dalam mata pelajaran bahasa Indonesia meningkatkan aktivitas mengajar guru dan aktivitas belajar siswa serta kemampuan membaca permulaan siswa

\section{KESIMPULAN \& SARAN}

Pemanfaatan media Big Book dapat meningkatkan hasil belajar bahasa Indonesia pada kemampuan membaca permulaan siswa kelas II SD Negeri Gunung Sari II Kecamatan Rappocini Kota Makassar. Peningkatan itu dapat dilihat dari siklus I aktivitas mengajar guru dan aktivitas belajar siswa berada pada kategori cukup, dan siklus II aktivitas mengajar guru dan aktivitas belajar siswa berada pada kategori baik. Hasil belajar pada siklus I belum mencapai ketuntasan secara klasikal dan siklus II sudah tercapai ketuntasan secara klasikal.

Disarankan bahwa dalam pembelajaran dengan memanfaatkan media Big Book dengan mengacu pada semua tahapan pembelajaran, layak dipertim-bangkan oleh para pengajar untuk menjadi media alternatif dalam melaksanakan pembelajaran yang lebih aktif dan menyenangkan pada mata pelajaran bahasa Indonesia khususnya sebagai media literasi di kelas awal. Disarankan para pengajar perlu memanfaatkan beberapa media pembelajaran, sehingga pelaksanaan pembelajaran dapat lebih bervariasi khususnya media literasi di kelas awal dan siswa tidak mengalami kebosanan dalam belajar dan akan lebih mudah memahami materi pelajaran, peneliti lain disarankan untuk melakukan penelitian pemanfaatan media Big Book pada tema lain dalam mata pelajaran bahasa Indonesia sehingga dapat memberikan sumbangan pengetahuan yang lebih bermanfaat bagi siswa.

\section{DAFTAR PUSTAKA}

Aisyah, Sitti., dan Arismanti, Yohana. 2000. Penggunaan Buku Besar (Big Book) dalam Mengembang-kan Kemampuan Berbahasa Anak (dengar-cakap-bacatulis) di TK. Jurnal Pendidikan (Online), Volume 3. Nomor1. http://www.lppm.ut.ac.id/jp/Volume\% 203.1\%20maret\%202002/31 aisyah.ht m, (diakses 05 Maret 2015)

Akhadiah M. K., Sabarti dkk. 1992/ 1993. Bahasa Indonesia I. Jakarta: Ditjen Dikti Kemen-dikbud.

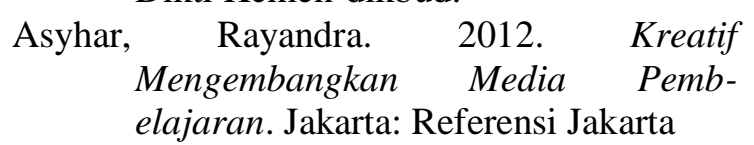


BSNP, 2006. Standar Isi: Standar Kompetensi dan Kompetensi Dasar SD/MI. Jakarta: BSNP.

Fitriani, Eka dan Bambang Yudi Cahyo. 2012.The Effectiveness of Implementing Big Book and Narative Scaffold on the Students'Achievement in Writing Narrative Texts. Jurnal Universitas Negeri Malang (Vol.1 Nomor 1Hlm. 1-13)

Kasihani K.E. Suyanto, 2007.english for young learners: Melijit Potensi Anak melalui English class yang fun, Asyik dam Menarik. Jakarta. PT. Bumi Aksara

Sadiman, Arief S dkk., 2009. Media Pendidikan:Pengertian, pengembangan \& Pemanfaatan-nya. Jakarta: Rajawali Pers.

Sugiyono. 2011. Motode Penelitian Pendidikan: Pendekatan Kuantitatif, Kualitatif dan $R \& D$. Bandung: Alfabeta.

Undang-Undang Sistem Pendidikan Nasional Nomor 2 Tahun 2003 tentang Sistem Pendidikan Nasional. Yogyakarta: Saufa
USAID, 2014. Buku Sumber untuk Dosen LPTK: Pembelajaran Literasi Kelas Awal di LPTK. Jakarta: USAID PRIORITAS.

Zuchdi, Darmiyanti dan Budiasih. 1996/1997. Pendidikan Bahasa dan Sastra Indonesia di Kelas Rendah. Jakarta: Depdikbud Ditjen Dikti

Zulela. 2013. Pembelajaran Bahasa Indonesia Apresiasi Sastra di Sekolah Dasar. Bandung: PT Remaja Rosdakarya 